\title{
Household Demand for Money in an Underdeveloped Economy : A Case Study of India
}

\author{
PREM S. LAUMAS and MARTIN Williams*
}

\begin{abstract}
The paper tries to overcome some of the empirical problems that are associated with the estimation of demand-for-money function in an underdeveloped economy. It deals explicitly with the choice of functional form and inclusion of interest rate as an explanatory variable to serve as opportunity cost of holding money in the money-demand function using both narrow and broad definitions of money. The paper concludes that short- or long-period interest rates serve as an opportunity cost of holding money in India only when a narrow definition of money is used. Time deposits were found to be sensitive to the maturity structure of financial instruments. As regards the choice of functional form, the paper holds that it makes no difference whether the function is estimated by linear form or by log-linear form. The paper also confirms for India the results of Friedman's seminal study for the United States.
\end{abstract}

\section{INTRODUCTION}

Considerable controversy has taken place among economists during the past few years on the question of the appropriate demand function for money balances. Briefly, this controversy has centred around five main empirical problems: (a) the definition of money to be used (whether to include time and/or savings deposits in money); (b) the appropriate constraint on money balances (whether it should be current income or wealth or Friedman's permanent income as a proxy for wealth); (c) the role of the rate of interest (whether the changes in money balances are at all dependent on changes in the rate of interest, and if so, is it the short rate or the long rate to which money balances respond most); (d) the specification of the most appropriate functional form, linear or log-linear, in estimating the demand-for-money equation; and (e) the question of stability of the demand-for-money function. ${ }^{1}$

*The authors are, respectively, Professor and Associate Professor of Economics in the Northern Illinois University, DeKalb. They are thankful to two anonymous referees fer constructive comments on an earlier version of this paper. Any remaining errors are, however, the authors' own responsibility.

${ }^{1}$ The first four issues are all discussed in the context of the more general issue relating to the stability of the demand_for_money function. With the recent development of econometric techniques, this issue has been widely discussed. See, for example, Rausser and P. Laumas [17] for Canada and G. Laumas and Mehra for the United States [13]. This issue, however, is not being discussed in this paper because P. Laumas [14] found the aggregate demand function for money to be stable. 
A number of studies on the demand for money have appeared for the less developed countries in an attempt to clarify the nature and significance of some of the above issues. But most of these studies suffer from at least three major weaknesses: (a) they use aggregate money income as a constraint on money balances rather than the income originating from the monetized sector even for economies that are significantly barter economies; (b) they fail to identify either the appropriate stock of money or the proper rate of interest on economic grounds; and (c) invariably they deal with the aggregate demand for money. Very little effort is made to study the demand for money by the household or the business sector.

The purpose of this paper is to overcome some of the weaknesses in other studies in our attempt to deal with the household demand for money in India. An explicit treatment of the appropriate function form is also provided here. Section II explains the data and the variables used. Section III presents the results and Section IV contains some concluding remarks.

\section{DATA SET}

Most economists agree that the demand-for-money function for real money balances (in per capita terms) may be specified as a positive function of real income and a negative function of the opportunity cost of holding money. The opportunity cost is the yield on alternative assets less the marginal payments of explicit and implicit interest on money. During a period of rising prices the expected rate of inflation should also be included along with the rate of interest or sometimes even as an alternative to the interest rate as the opportunity cost of holding money. However, during the period under study the price level was fairly stable.

In this paper it is not possible to use per capita real income since it is difficult to determine that part of the household population which contributes to the monetized part of the household disposable income. ${ }^{2}$ All variables have been deflated in terms of the 1960-61 GNP deflator.

Considerable discussion has taken place on the choice of the proper rate of interest that may represent the most appropriate opportunity cost of holding money.

${ }^{2}$ Three major steps are involved in calculating the monetized portion of household disposable income. First, net household disposable income is arrived at as follows: net domestic product at factor cost minus income from domestic production accruing to government plus national debt interest plus earned income from abroad plus transfer payment plus net private donations from abroad minus all direct taxes and retained earnings of companies; second, estimates for the self-consumption of foodgrains for 1958-59 were obtained by making use of the ratio method of estimation. The ratio of kind expenditure to total expenditure on foodgrains represented the portion of self-consumption of cereals. For the years before 1958-59 and after 1958-59 similar estimates are obtained by considering the rate of growth of rural population to be $2.0 \%$ to $1960-61$ and $2.4 \%$ afterwards. Third, the figures of the self consumption of foodgrains, thus obtained are subtracted from net disposable income to arrive at estimates of the monetized part of the household disposable income over the time period.
Eisner [5] and Latane [11], for example, use an interest rate on long-term bonds, since Keynes linked the long-term rate to investment and income through the demand for and the supply of money. Others such as Brunner and Meltzer [4] and Hamburger [8] have argued that the demand for money ought to be treated in a theory of portfolio selection and suggest that the demand for money depends on the yield on equities as well as bonds. Still others such as Bronfenbrenner and Mayer [3], Teigen [18], Heller [9] and Laidler [10] view a short-term rate as the most appropriate rate; for it indicates best the opportunity cost of holding money instead of close substitutes. From the empirical point of view, however, such a discussion is not very enlightening. During the period under consideration the only interest-bearing assets that were available and held by the public were the various types of longterm government securities and time deposits at the scheduled banks (same as member banks in the United States). Since these rates have not moved hand in hand and since no index of composite rate is available, we use the average government securities rate and the average time deposit rate as measure of the opportunity cost of holding money by the household sector in India. ${ }^{3}$

Economists are not in complete agreement over the question of the most appropriate stock of money suitable for a study of the demand for money. Some favour a narrow stock of money, $M_{1}$, currency outside scheduled banks and demand deposits at the scheduled banks, while others advocate the broad concept of money, $M_{2}$, which in addition includes the time deposits at the scheduled banks. The Reserve Bank of India feels, however, that in the Indian case there are reasons to favour $M_{2}$ stock of money. "Time deposits in India have the traits of current and fixed deposits and their allocation into demand and time portions has certain element of arbitrariness. With the progressive liberalization of rules regarding the withdrawal from such deposits over the years, an increasing proportion of these is getting reflected under demand deposits. Furthermore, there is some empirical evidence to show that there is substitution between demand and time deposits during the busy and slack seasons of any year. By defining money to include time deposits also, the results obtained would be free from any bias on this score." 4

The sample period for this study is 1952.53 to 1967.68 . These are the only years for which reliable data on monetized disposable income for the households and their money holdings are available for India. ${ }^{5}$ Following Friedman, some economists have advocated the use of permanent income instead of current income as the appropriate constraint on money balances. But we refrained from this due to the lack of

${ }^{3}$ For details of the averaging method and the appropriate weights attached to various types of time deposits and government securities see Kamta Prasad, [16, pp. 160-161].

${ }_{5}^{4}$ The Reserve Bank of India Bulletin. June 1972. p. 949; and April 1966, p. 362.

${ }^{5}$ The Reserve Bank of India. June 1972. p. 958. 
adequate relevance of the Permanent Income Hypothesis to the Indian conditions. ${ }^{6}$ In addition, the data available to us are not sufficient for the calculation of permanent income.

\section{METHODOLOGY AND RESULTS}

On the subject of demand for money, the most commonly used functional forms are either linear or log-linear. Economic theory underlying the demand for money, however, does not provide any a priori basis for selecting one form over the other. Most economists, however, have viewed the choice of the proper functional form as essentially an empirical problem. Recently Box and Cox [2] have suggested a procedure which helps to discriminate between the linear and the log-linear functional forms for their appropriateness for a given problem. In estimating the household demand-for-money function for India we use the Box-Cox procedure. We may explain this briefly. Consider a general functional form of the demand function as:

$$
M_{t}^{(\lambda)}=\beta_{0}+\sum_{i=1}^{P} \beta_{i} X_{i t}^{(\lambda)}+e_{t} \quad \cdots
$$

where $M_{t}$ is the demand for money at time $t ; X_{i t}$ are the explanatory variables at $t,=$ $1,2, \ldots, p$ and $e_{t}$ is an error term. The Box-Cox transformation is:

$$
\begin{aligned}
M_{t}(\lambda)=\frac{M_{t}-1}{\lambda} \text { when } \lambda \neq 0 & \\
\ln M_{t} \quad \lambda & =0 \\
X_{i t}(\lambda)=\frac{X_{i t}^{\lambda}-1}{\lambda} \text { when } \lambda & \neq 0 \\
\ln X_{i t} & =1,2, \ldots, P \\
& =0
\end{aligned}
$$

Clearly, when $\lambda=1$, equation (1) becomes linear and when $\lambda=0$, the equation becomes linear in the logarithms. From equation (1) different values of $\lambda$ give different functional forms.

The Box-Cox transformation procedure is used to estimate the values of $\lambda$ and the other parameters in equation (1). Using the maximum-likelihood estimation method, we can estimate $\lambda$ and other parameters under the assumption that $e_{t}$

\footnotetext{
${ }^{6}$ See Laumas and Laumas [12], pp. 289-296.
}

is normally and independently distributed. The advantages of the Box-Cox transformation can be summarized as follows:

(a) The resulting transformation is a consequence of the estimation, not an $a$ priori specification;

(b) The method allows the sample data to dictate the appropriate functional form from the set of functional forms described by equation (1). The linear and $\log$-linear forms are special cases of the class of transformations. Thus the estimated functional form is empirically obtained from the sample data; and

(c) The estimation technique allows a more direct test whereby we can compare alternative functional forms rather than accept a predetermined functional form as a maintained hypothesis. ${ }^{7}$

We have postulated the demand for money to be a function of income and a rate of interest. Based on these considerations, the initial statistical model for the demand for money in India is as follows:

$$
M_{t}^{(\lambda)}=\beta_{0}+\beta_{1} Y_{i t}(\lambda)+\beta_{2} r_{i t}(\lambda)+e_{t}
$$

where $M_{t}=$ money is defined as (a) $C$ for currency, (b) $T D$ for time deposits, (c) $M_{1}$ for the narrow stock of money and (d) $M_{2}$ for the broad stock of money; $Y_{i t}=$ monetized disposable income; $r_{i t}=$ the rate of interest where (a) $R_{1}$ represents the weighted short-term rate and (b) $R_{2}$ the weighted long-term rate; and $e_{t}$, an error term, is assumed to be distributed as an independent normal random variable with zero mean and constant variance. Recall that the transformation of $M_{t}(\lambda)$ and $Y_{i t}{ }^{(\lambda)}$ and $r_{i t}{ }^{(\lambda)}$ were previously defined.

Tables 1 and 2 present the results of this study. Note that monetized disposable income of the household sector in India and two types of interest rate, a weighted average short rate $\left(R_{1}\right)$ and a weighted average long rate $\left(R_{2}\right)$, are the independent

${ }^{7}$ Using the maximum-likelihood estimation method, $\lambda$ and other parameter can be estimated, under the assumption that $e$ is normally and independently distributed. Omitting some constants, the maximum-likelihood function of equation (1) with respect to $\lambda$ is given as:

$$
L_{\max }^{(\lambda)}=\frac{\eta}{2} \ln \underset{(\lambda)}{\hat{\sigma}^{2}}+(\lambda-1) \sum_{t} \ln M_{t}
$$

where $\sigma^{-2}$ is the estimated error variance of the regression of $M_{t}(\lambda)$ on $X_{1 t}(\lambda), x_{2 t}(\lambda), \ldots$, $(\lambda)$

$X_{p t}(\lambda)$. The optimal value of $\lambda$ is selected which maximizes equation (3). Box-Cox also indicates that one ccnfidence level $(1-\alpha)$ for $\lambda$ based on the results that $2\left[L \underset{\max }{(\lambda)}-L_{\max }(\lambda)\right]$ is distributed as $X_{2}$ (chi-square) with one degree of freedom. The values of $L \underset{\max }{\hat{\lambda_{x}}}$ denotes the values of the unrestricted maximum of the likelihood function and $1(\hat{\max })$ denotes the value of the restricted maximum of the likelihood function. 
variables in the demand-for-money function. $M_{2}$ is the dependent variable since, as pointed out above, the Reserve Bank of India views the broad concept of money as the most relevant in formulating monetary policy in India. However, since currency is a predominant part of money supply, we also provide estimates for the demand for currency $(C)$ by the households. In addition, we provide separate estimates on the demand for time deposits (TD) since it is believed that time accounts at the scheduled banks are widely used as instruments of savings by the households.

Since the GBC, linear and log-linear models are members of the same family of parametric functions, a likelihood-ratio test can be used to determine whether the "goodness of fit" of the linear models and log-linear models is significantly different from that of the GBC model. The test is based on the Chi-squared distribution. The GBC model is unrestricted, whereas the linear model and log-linear model have the restrictions $\lambda=1.0$ and $\lambda=0.0$ respectively.

The results of the pairwise comparisons are presented in Table 2. These comparisons indicate that the null hypothesis of no difference in the goodness of fit in the linear and log-linear specifications relative to the goodness of fit in the generalized functional form would be rejected at the 0.5 -percent level of significance. This result lends considerable support to the validity of the linear and log-linear functions of demand for money by households in India.

For purposes of comparison we present estimates of income and interest elasticities based on the linear and log-linear functions. For the linear models the elasticities are computed at the mean of the data. ${ }^{8}$

The results in Table 1 with the $M_{2}$ concept of money indicate that the income elasticity of the demand for money is 1.22 and the income elasticity of the demand for time deposits is 1.78 . This means that money and, especially, time deposits are a luxury good. The luxury good hypothesis requires that the coefficient of income be greater than one when the logarithm of money is regressed on the logarithm of income.

In the advanced industrial economies with highly developed financial markets interest rate in the demand-for-money functions serves as the opportunity cost of holding money. Therefore, one would expect the coefficient of interest elasticity to be negative. However, in this study we find that the value of the interest elasticity of the demand for money with the $M_{2}$ concept of money and the short-term interest rate is positive $(0.24)$ and significant. This confirms the results of some studies on other underdeveloped economies that due to the availability of a limited number of financial instruments households tend to keep their savings in the form of money. ${ }^{9}$

${ }^{8}$ The interest elasticities for the short- and long-term rates for the linear models in Table 1 are as follow/s: $M_{2}(0.27),(0.17) ; T D(0.75),(0.65) ; C(-0.27),(0.008)$; the income elasticities for the corresponding models of short-and long-term rates are: $M_{2}(1.07),(1.32) ; T D(1.40)$, (1.76) and $C(1.19),(0.95)$.

${ }^{9}$ See, for example, Lee [15], and Trescott [19].

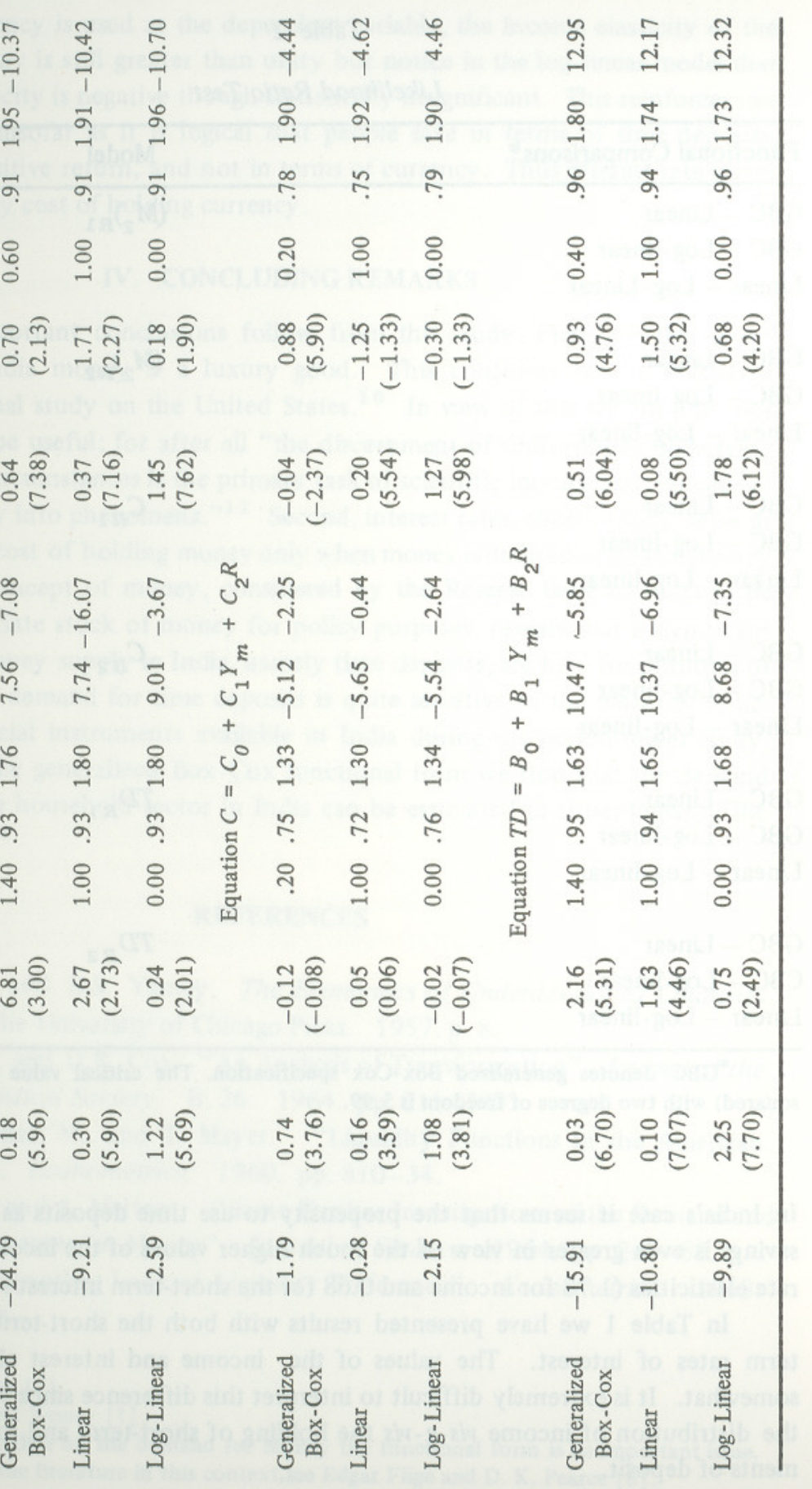


Table 2

Likelihood Ratio Test

\begin{tabular}{lcc}
\hline Functional Comparisons* & Model & $\chi^{2}$ \\
\hline GBC - Linear & $\left(M_{2}\right)_{R 1}$ & 0.36 \\
GBC - Log-linear & & 2.54 \\
Linear - Log-Linear & & 2.18 \\
GBC - Linear & $\left(M_{2}\right)_{R 2}$ & 0.10 \\
GBC - Log-linear & & 0.66 \\
Linear - Log-linear & & 0.56 \\
GBC - Linear & $C_{R 1}$ & 1.06 \\
GBC - Log-linear & & 0.84 \\
Linear - Log-linear & & 0.22 \\
GBC - Linear & & \\
GBC - Log-linear & $C_{R 2}$ & 0.36 \\
Linear - Log-linear & & 0.04 \\
GBC - Linear & & 0.32 \\
GBC - Log-linear & $T D_{R 1}$ & 1.56 \\
Linear - Log-linear & & 1.26 \\
GBC - Linear & & 0.30 \\
CBC - Log-linear & & 0.20 \\
Linear - Log-linear & & 3.58 \\
\hline
\end{tabular}

${ }^{*} \mathrm{GBC}$ denotes generalized Box-Cox specification. The critical value of the $\chi_{2}$ (Chisquared) with two degrees of freedom is 5.99 .

In India's case it seems that the propensity to use time deposits as instruments of savings is even greater in view of the much higher values of the income and interestrate elasticities ( 1.78 for income and 0.68 for the short-term interest rate).

In Table 1 we have presented results with both the short-term and the longterm rates of interest. The values of the income and interest elasticities differ somewhat. It is extremely difficult to interpret this difference since we do not know the distribution of income vis- $a$-vis the holding of short-term and long-term instruments of deposit.
When currency is used as the dependent variable, the income elasticity of the demand for money is still greater than unity but notice in the log-linear model that the interest elasticity is negative though statistically insignificant. This reinforces our previous results insofar as it is logical that people save in terms of time deposits, which have a positive return, and not in terms of currency. Thus interest rate serves as the opportunity cost of holding currency.

\section{CONCLUDING REMARKS}

Several important conclusions follow from this study. First, for the household sector in India money is a luxury good. This conforms to the results of Friedman's seminal study on the United States. ${ }^{10}$ In view of this we consider this investigation to be useful; for after all "the discernment of uniformities underlying the diversity of circumstances is the primary task of scientific inquiry and, indeed, all systematic inquiry into phenomena."11 Second, interest rates, short or long, serve as the opportunity cost of holding money only when money is defined to mean currency alone. The $M_{2}$ concept of money, considered by the Reserve Bank of India to be the most appropriate stock of money for policy purposes, reveals that a significant component of money supply in India, namely time deposits, are held for purposes of savings. And the demand for time deposits is quite sensitive to the maturity structure of the financial instruments available in India during the period under study. Third, based on the generalized Box-Cox functional form we find that the demand for money for the household sector in India can be estimated in either linear or the $\log$-linear forms. ${ }^{12}$

\section{REFERENCES}

1. Bauer, P.T., and B.S. Yamey. The Economics of Underdeveloped Countries. Chicago: The University of Chicago Press. 1957. p. 8.

2. Box, G.E.P., and D.R. Cox. "An Analysis of Transformation". Journal of the Royal Statistical Society. B, 26. 1964. pp. 211-243.

3. Bronfenbrenner, M., and T. Mayer. "Liquidity Functions in the American Economy". Econometrica. 1960. pp. 810-34.

4. Brunner, K., and A. Meltzer. "Some Further Investigations of the Demand and Supply Functions for Money”. Journal of Finance. 1964. pp. 240-83.

5. Eisner, R. "Another Look at Liquidity Preference". Econometrica. 1963 pp. $531-38$.

${ }^{10}$ See Friedman [7].

${ }_{12}^{11}$ See Bauer and Yamey [1].

${ }^{12}$ For some studies on the demand for money the functional form is an important issue For a brief survey of the literature in this context,see Edgar Flige and D. K. Pearce [6]. 
6. Flige, E., and D. K. Pearce. "The Substitutability of Money and Near Monies". Journal of Economic Literature. 1979. pp. 439-69.

7. Friedman, M. "The Demand for Money - Some Theoretical and Empirical Results”. Journal of Political Economy. 1959. pp. 327-351.

8. Hamburger, M. J. "The Demand for Money by Households, Money Substitutes and Monetary Policy". Journal of Political Economy. 1966. pp. 600-23.

9. Heller, H. R. "The Demand for Money: Evidence from Short-Run Data". Quarterly Journal of Economics. 1965. pp. 291-303.

10. Laidler, D. "The Rate of Interest and the Demand for Money: Some Empirical Evidence”. Journal of Political Economy. 1966. pp. 55-58.

11. Latane, H. A. "Income Velocity and Interest Rates: A Pragmatic Approach". Review of Economic Statistics. 1960. pp. 445-49.

12. Laumas, G.S., and Prem S. Laumas. "The Permanent Income Hypothesis in an Underdeveloped Economy”. Journal of Development Economics. 1976. pp. 289-296.

13. Laumas, G., and Yash P. Mehra. "The Stability of the Demand for Money Functions: Evidence from Short-Run Data". The Review of Economics and Statistics. 1976. pp. 463-468.

14. Laumas, Prem S. "Monetization, Economic Development and the Demand for Money". The Review of Economics and Statistics. 1978. pp. 614-618.

15. Lee, S. Y. "Money, Quasi-Money and Income Velocity of Circulation in Malaya and Singapore, 1946-1965". Economic Development and Cultural Change. 1971.pp. 287-312.

16. Prasad, K. The Role of Monetary Policy in a Developing Economy: A Theoretical and Empirical Analysis. Bombay: Allied Publishers. 1969. pp. 160-161.

17. Rausser, G.C., and Prem S. Laumas. "The Stability of the Demand for Money in Canada". Journal of Monetary Economics. 1976. pp. 367-80.

18. Teiger, R. L. "Demand and Supply Functions for Money in the United States: Some Structural Estimates”. Econometrica. October 1964. pp. 476-509.

19. Trescott, Paul B. "Money, Quasi-Money and Other Liquid Assets in Thailand, 1946-67". Economic Development and Cultural Change. January 1972. 